\title{
DOES URINARY TRACT ULTRASOUND HAVE ITS PLACE IN THE TREATMENT OF EARLY NEONATAL JAUNDICE? NEONATAL BILATERAL ADRENAL HEMORRHAGE: CASE REPORT
}

\author{
Ivana Trutin ${ }^{1}$, Bernardica Valent Morić ${ }^{1}$, Jesenka Borošak ${ }^{2}$ and Gordana Stipančić ${ }^{1}$ \\ ${ }^{1}$ Department of Pediatrics, Sestre milosrdnice University Hospital Centre, Zagreb, Croatia; \\ ${ }^{2}$ Department of Gynecology and Obstetrics, Sestre milosrdnice University Hospital Centre, Zagreb, Croatia
}

\begin{abstract}
SUMMARY - Adrenal hemorrhage is a rare clinical entity in the neonatal period, with an incidence of 1.7-2.1/1000 births. It is more often diagnosed on the right side, whilst bilateral hemorrhage occurs in $10 \%-15 \%$ of cases. Clinical presentation shows a wide range of symptoms, from the signs of adrenal insufficiency to asymptomatic course of illness with incidental finding of changes on testing. Neonatal jaundice due to hemolysis of hemorrhagic content often is an accompanying sign. We present a male neonate born at term, with early neonatal jaundice of unknown cause and without evidence of perinatal infection. Ultrasound of the urinary tract revealed hypoechoic formations in the upper poles of both kidneys, confirmed by magnetic resonance imaging of the abdomen. Clinical and laboratory test results showed no signs of adrenal insufficiency. There was no confirmation of embryonic tumor or neuroblastoma. Ultrasound of the urinary tract as an available and noninvasive test has its place in the treatment of early neonatal jaundice of unknown cause. Additional invasive treatment and unnecessary laparotomy can be avoided with ultrasound monitoring of the formation regression.
\end{abstract}

Key words: Adrenal gland diseases; Hemorrhage; Adrenal insufficiency; Jaundice, neonatal; Infant, newborn

\section{Introduction}

Adrenal hemorrhage develops mostly due to birth trauma, large birth weight, asphyxia and hypoxia, sepsis, coagulation disorders, and may also arise spontaneously. Adrenal glands are relatively large and of increased vascularization in the neonatal period, which contributes to the vulnerability due to mechanical compression and sensitivity with changes in venous pressure during childbirth. It is more often diagnosed on the right side, and is bilateral in 10\%-15\% of cases ${ }^{1}$.

Clinical presentation shows a wide range of symptoms, from the signs of adrenal insufficiency to asymp-

Correspondence to: Ivana Trutin, $M D$, Department of Pediatrics, Sestre milosrdnice University Hospital Centre, Vinogradska c. 29, HR-10000 Zagreb, Croatia

E-mail: ivana.trutin@gmail.com

Received October 6, 2016, accepted November 9, 2016 tomatic course of illness with incidental finding of changes on testing. Neonatal jaundice due to hemolysis of the hemorrhagic content is a common symptom ${ }^{2}$. Adrenal hemorrhage may present as a palpable abdominal mass, discoloration of the scrotum due to leakage of blood from the retroperitoneal space through the processus vaginalis, as well as hemorrhagic shock with hypotension and anemia ${ }^{3}$.

Differential ultrasound diagnosis of cystic formation in the projection of the adrenal gland requires exclusion of the presence of cystic neuroblastoma, embryonic tumors, adrenal abscess, dual channel system with hydronephrosis of the upper renal pole, cortical renal cysts and multicystic kidney ${ }^{4}$.

In almost all cases, adrenal hemorrhage is spontaneously absorbed within three months after birth but requires ultrasound monitoring. 


\section{Case Report}

A male infant was born from the third pregnancy burdened with gestational diabetes that was under control by diet. Prenatal ultrasound was normal, triple test showed low risk. Family history was inconspicuous. The baby was born in $40^{\text {th }}$ week of gestation by vaginal delivery, birth weight $3880 \mathrm{~g}\left(75^{\text {th }}\right.$ percentile $)$ and length $51 \mathrm{~cm}$ ( $35^{\text {th }}$ percentile). Apgar scores at 1 and 5 minutes were 10 and 10, respectively. He received vitamin K. After birth, he was vibrant, afebrile, of normal status, with parietal right small birth swelling, abdomen without palpable formation and without organomegaly. At the age of 25 hours, due to yellowing of the skin blood tests were done $(\mathrm{C}$-reactive protein (CRP) 36.6. $\mathrm{mg} / \mathrm{L}$, procalcitonin $4.91 \mathrm{ng} / \mathrm{mL}$, total bilirubin $198 \mathrm{pmol} / \mathrm{L}$ and conjugated bilirubin 15 $\mu \mathrm{mol} / \mathrm{L}$, indicating unconjugated hyperbilirubinemia). Blood cell count, creatinine, blood urea nitrogen, blood sugar, serum electrolytes, liver function tests, urinalysis, and acid-base status were within the normal limits.

Double empirical therapy with ampicillin and gentamicin was started, with continuous phototherapy from $1^{\text {st }}$ to $3^{\text {rd }}$ day of life. Arterial pressures and vital parameters were normal all the time. Microbiological tests (blood cultures, urine culture, nasopharyngeal smear) were normal. The mother had A Rh positive blood group, and the child was $\mathrm{O}$ Rh positive, direct Coombs negative. Brain ultrasound was performed on $7^{\text {th }}$ day of life to show periventricular leukomalacia, more voluminous plexuses, and suspect state after periventricular/intraventricular degree I/II hemorrhage to the right.

After seven days of antibiotic therapy, CRP as an inflammatory parameter was still high but without clear site of infection, indicating urinary tract ultrasound for suspicion of the possible urinary system anomaly. The examination showed cystic formations in the upper poles of both kidneys sized $4.5 \times 3 \mathrm{~cm}$ (Figs. 1 and 2).

On $15^{\text {th }}$ day of life, magnetic resonance imaging (MRI) of the abdomen showed suspect bilateral adrenal hemorrhage, visualized as cystic formations in both adrenal glands, sized $3.2 \times 2.3 \times 4 \mathrm{~cm}$ in the right kidney and $3.4 \times 3.1 \times 4 \mathrm{~cm}$ in the left kidney (Figs. 3 and 4 ).

Additional tests did not indicate development of adrenal insufficiency (adrenocorticotropic hormone $(\mathrm{ACTH})$, cortisol, plasma renin activity and aldoste-

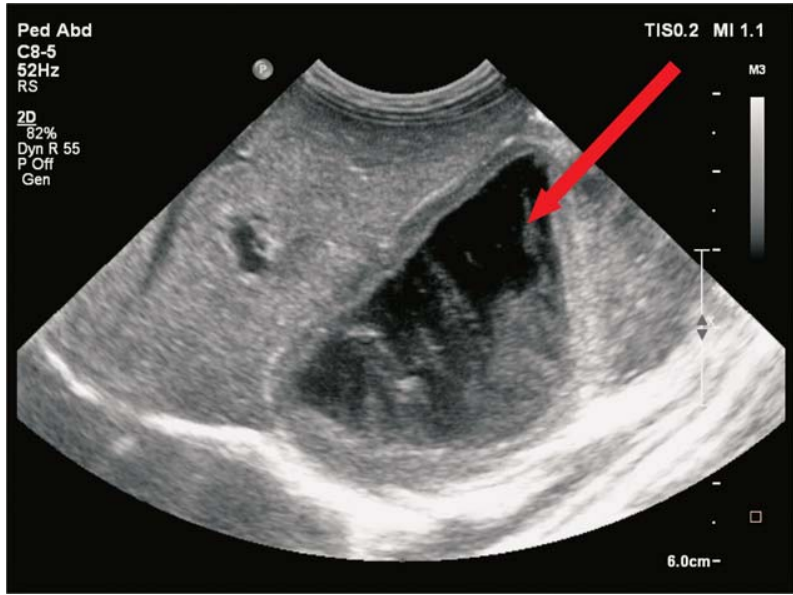

Fig. 1. Ultrasound showing right adrenal hematoma (seventh day of life).

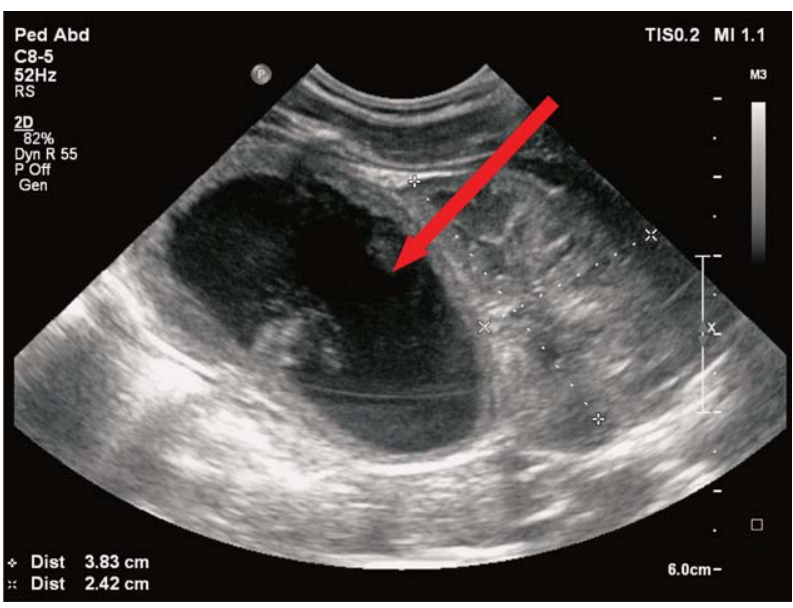

Fig. 2. Ultrasound showing left adrenal hematoma (seventh day of life).

rone were within the normal range for age). Results of alpha fetoprotein were increased on $8^{\text {th }}$ day $(41,648$ $\mathrm{ng} / \mathrm{mL})$ and $15^{\text {th }}$ day of life $(13,974 \mathrm{ng} / \mathrm{mL})$. Results of vanillylmandelic acid, adrenaline and noradrenaline in 24-h urine and beta human chorionic gonadotropin in serum were within the normal limits. Testing showed no coagulation disorders.

Neuron-specific enolase was slightly increased on $10^{\text {th }}$ day of age $(81.6 \mathrm{ng} / \mathrm{mL})$, but decreased to $27.5 \mathrm{ng} /$ $\mathrm{mL}$ and $17.1 \mathrm{ng} / \mathrm{mL}$ on 30 -day and 4-month follow up, respectively (reference value $<25 \mathrm{ng} / \mathrm{mL}$ ). On follow up at the age of 1.5 months, alpha fetoprotein was $224.1 \mathrm{ng} / \mathrm{mL}$ (reference value $<7 \mathrm{ng} / \mathrm{mL}$ ). Decreasing neuron-specific enolase levels recorded on follow up 

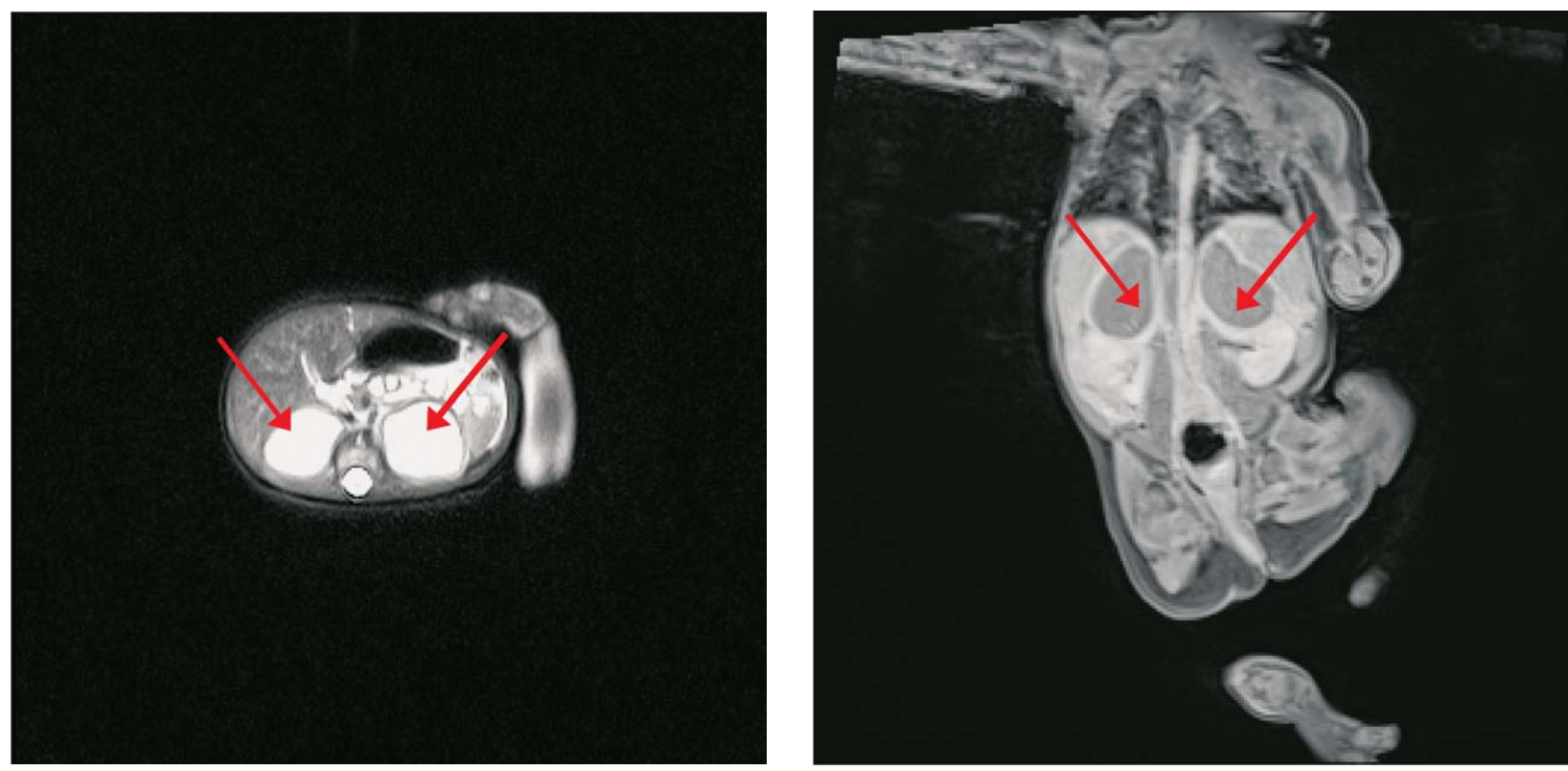

Figs. 3 and 4. Magnetic resonance image showing bilateral adrenal hemorrhage (ninth day of life).

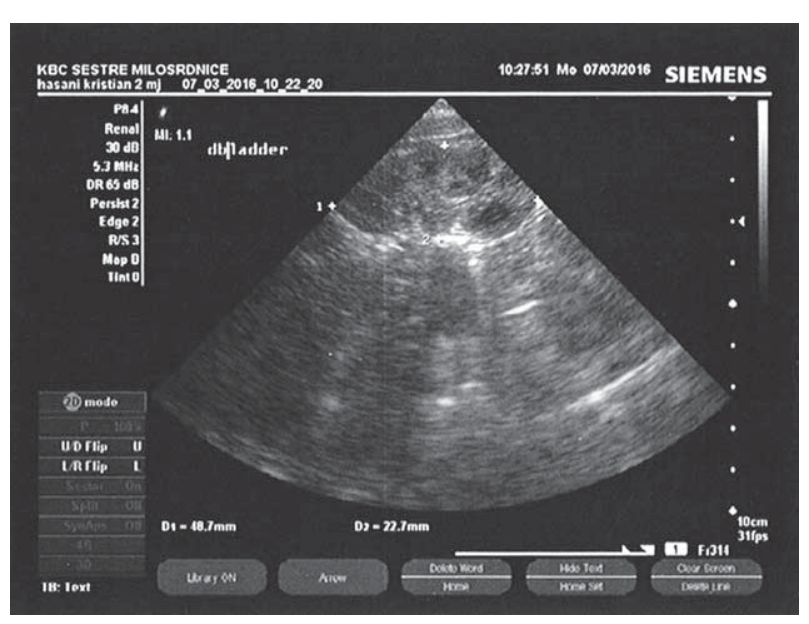

Fig. 5. Follow-up ultrasound 3 months later showing almost complete resolution of the hematoma.

testing spoke against the diagnosis of cystic neuroblastoma, while the results of alpha fetoprotein were in accordance with the physiological dynamics postnatal decline.

At discharge on $17^{\text {th }}$ day of life, follow up ultrasound of the urinary tract showed partial regression of the formations. Dimensions of the hypoechoic formations in the upper poles of both kidneys were slightly smaller; the left measured $3.6 \times 2.3 \mathrm{~cm}$ and right $3.9 \times 2$ $\mathrm{cm}$, with visible septa in both formations. Further ultrasound monitoring of the formations showed com- plete formation regression within 3 months after birth (Fig. 5).

Subsequent clinical follow up was without any signs that would indicate adrenal insufficiency (loss of appetite, vomiting, diarrhea, malaise), along with satisfactory cortisol and ACTH results.

\section{Discussion}

Our patient developed early neonatal jaundice, which was understood as a sign of perinatal infection, as indicated by increased inflammatory parameters, after which double empirical antibiotic therapy was introduced. As part of the treatment needed to determine the source of infection, ultrasound of the urinary tract was performed to show hypoechoic formations in the upper poles of both kidneys. Ultrasound showed a suspect bilateral hemorrhage in the adrenal gland, while MRI confirmed the diagnosis.

Early neonatal jaundice is an uncommon but very important phenomenon, usually caused by $\mathrm{Rh}$ and $\mathrm{ABO}$ incompatibility of the mother and the newborn, hemolytic anemia, enzyme deficiency, perinatal infection, hypothyroidism, or hemolysis within the hematoma ${ }^{5}$. In $30 \%$ of cases, it is of unknown etiology.

Adrenal hematoma is usually unilateral and located on the right in $70 \%$ of cases, and bilaterally in only $10 \%$ of all cases of adrenal hemorrhage. Right localization of 
hematoma is more common because of the greater likelihood of compression of adrenal gland between the liver and the spine, and the fact that the right adrenal vein drains directly into the lower venous cavity and is more susceptible to changes in venous pressure ${ }^{1}$.

A certain percentage of adrenal hemorrhage occurs spontaneously. Any event related to hypoxia and asphyxia leads to diverting blood flow to vital organs. Hypoxia leads to damage to endothelial cells, making them more prone to bleeding, which explains hematoma in adrenal gland in the neonatal period, usually during hypoxia and asphyxia during birth. In our case, there was no risk factor for bleeding in the adrenal gland, but the bleeding occurred spontaneously.

Early neonatal jaundice occurring as a result of hemolysis within the hematoma is a rare primary presentation of adrenal hemorrhage, but our patient presented early neonatal jaundice with increased inflammatory parameters without clear site of infection ${ }^{2}$.

Cystic neuroblastoma is the most common malignancy that occurs perinatally, and adrenal gland is the most common site of primary localization. Cystic neuroblastomas are often complicated by bleeding within the formation, and it is difficult to distinguish neuroblastoma and adrenal hematoma, since the value of catecholamines in urine may be normal after birth.

Postnatal diagnosis of cystic neuroblastoma requires laboratory tests to determine neuron-specific enolase, catecholamines in 24-h urine, and MRI of the abdomen ${ }^{4}$. There are rare cases of cystic neuroblastoma that can be spontaneously partially absorbed, therefore ultrasound follow up after birth is very important. After 90 days, mostly all adrenal hematomas but not cystic neuroblastomas are spontaneously resorbed. The preferred dynamics of ultrasound follow up of adrenal hemorrhage is monthly for the first three months, then every 3 months until complete regression ${ }^{6}$.

Exclusion of the existence of embryonic tumors requires determination of serum levels of alpha fetoprotein and beta chorionic gonadotropin.

After birth and in early infancy, alpha fetoprotein levels are elevated due to the synthesis in the fetal liver (normal range in neonate, 17200-44350 ng/mL). Alpha fetoprotein values normalize to the adult reference values at 8 months of age ${ }^{7}$. The diagnosis of embryonic tumor can be excluded by monitoring the dynamics of decline in the alpha fetoprotein values, as it was the case in our patient.
The examinations performed in our patient ruled out the existence of cystic neuroblastoma (monitoring the dynamics of decline of the neuron-specific enolase values to normal values at 4 months of age), while the increased levels of alpha fetoprotein followed the pattern of physiological postnatal decline.

Reference values of plasma renin activity and aldosterone are higher at neonatal and infant age and are inversely proportional to age. The explanation lies in the weakened neonatal cortical perfusion of the kidney, resulting in increased renal vascular resistance. At the same time, the proximal tubular function is immature, resulting in an increased inflow of filtered sodium to the macula densa, stimulating renin release and indirectly enhancing reabsorption of sodium in the distal tubule ${ }^{8}$.

It is necessary to exclude adrenal insufficiency and perform ACTH, cortisol, aldosterone, plasma renin activity and serum ionogram testing, which were within the normal range for age in our patient. Adrenal crisis is a possible but relatively rare manifestation because bleeding is predominantly subcapsular and adrenal crisis does not occur unless more than $90 \%$ of adrenal tissue is destroyed ${ }^{9}$. Long-term follow up is necessary for the possible development of adrenal insufficiency in case of infection or stress.

An increased risk of urinary tract infection due to compression of the upper pole of the kidney hematoma has been described, leading to urinary retention in cups and disorders of antireflux mechanism of the papillae, resulting in intrarenal reflux because of calico-tubular inverse flow of urine. This creates a predisposition for the development of acute urinary tract infection ${ }^{10}$.

Based on the fact that prenatal ultrasound did not verify any formation in the abdomen, history of the delivery, lack of hypoxic-ischemic injury, MRI finding of the abdomen and ultrasound of the urinary tract, endocrine tests that excluded the existence of neuroblastoma and embryonal tumors, and ultrasound showing formation regression within 3 months, we concluded that it was a bilateral adrenal hemorrhage of spontaneous origin. Ultrasound examination is the most appropriate method for the diagnosis of adrenal hemorrhage, as well as to monitor adrenal hematoma, owing to its simple use and lack of exposure to irradiation.

Early neonatal jaundice may be the only clinical sign of adrenal hemorrhage. Therefore, ultrasound of the urinary tract is important in the treatment of early neona- 
tal jaundice of unknown cause. Additional invasive treatment and unnecessary laparotomy can be avoided with ultrasound monitoring of the formation regression.

\section{References}

1. Demirel N, Yagmur Bas A, Zenciroglu A, Tasci-Yildiz Y. Adrenal bleeding in neonates: report of 37 cases. Turk J Pediatr. 2011;53:43-7.

2. Ruffini E, De Petris L, Zorzi G, Paoletti P, Mambelli G, Carlucci A. Two cases of neonatal adrenal hemorrhage presenting with persistent jaundice. Pediatr Med Chir. 2013;35:285-7. https://doi.org/10.4081/pmc.2013.26

3. Yarci E, Arayici S, Nur Sari F, Emre Canpolat F, Uras N, Dilmen U. Adrenal hemorrhage presenting as a scrotal hematoma in the newborn; a case report. Arch Argent Pediatr. 2015; 113:161-3. http://dx.doi.org/10.5546/aap.2015.e161

4. Orun E, Yildirim M, Esra Yilmaz A, Tufan N. Is routine abdominal ultrasonography necessary in macrosomic newborns with difficult delivery? J Matern Fetal Neonatal Med. 2012; 25:1195-6. https://doi.org/10.3109/14767058.2011.614661

5. Katar S, Ozturkmen-Akay H, Devecioglu C, Taskesen M. A rare cause of hyperbilirubinemia in a newborn: bilateral adrenal hematoma. Turk J Pediatr. 2008;50:485-7.

6. Mutlu M, Karaguzel G, Aslan Y, Cansu A, Okten A. Adrenal hemorrhage in newborns: a retrospective study. World J Pediatr. 2011;7:355-7. https://doi.org/ 10.1007/s12519-011-0259-7

7. Blohm ME, Vesterling-Horner D, Calaminus G, Gobel U. Alpha 1-fetoprotein (AFP) reference values in infants up to 2 years of age. Pediatr Hematol Oncol. 1998;15:135-42.

8. Dillon MJ, Ryness JM. Plasma renin activity and aldosterone concentration in children. Br Med J. 1975;4:316-9.

9. White PC. Adrenocortical insufficiency. In: Behrman RE, Kliegman RM, Jenson HB, eds. Nelson Textbook of Pediatrics. Philadelphia: WB Saunders, 2007; p. 2357-8.

10. Habeb AM, Zulali MA, Yamani AS, Yassine SM. Neonatal adrenal hematoma with urinary tract infection: risk factor or a chance association? Saudi J Kidney Dis Transpl. 2014;25: 376-80.

Sažetak

\section{IMA LI ULTRAZVUK MOKRAĆNOG SUSTAVA MJESTO U OBRADI RANE NOVOROĐENAČKE ŽUTICE? OBOSTRANO KRVARENJE U NADBUBREŽNU ŽLIJEZDU KOD NOVOROĐENČETA: PRIKAZ SLUČAJA}

\section{Trutin, B. Valent Morić, J. Borošaki G. Stipančić}

Adrenalna hemoragija je rijedak klinički entitet u novorođenačkoj dobi, s incidencijom od 1,7-2,1/1000 novorođenih. Češce se dijagnosticira na desnoj strani, a u 10\%-15\% slučajeva je obostrana. Klinička prezentacija je širokog spektra, od znakova adrenalne insuficijencije do asimptomatskog tijeka uz slučajan nalaz promjene na slikovnim pretragama. Neonatalna žutica zbog hemolize hemoragičnog sadržaja čest je prateći znak. Iznosimo prikaz muškog novorođenčeta rođenog u terminu s ranom neonatalnom žuticom nepoznatog uzroka i bez dokazanog perinatalnog infekta. Učinjen je ultrazvuk mokraćnog sustava, koji je pokazao hipoehogene tvorbe u području gornjeg pola oba bubrega, što je potvrđeno i magnetskom rezonancom abdomena. Klinički i laboratorijski nije bilo znakova insuficijencije nadbubrežne žlijezde. Nije bilo potvrde embrionalnog tumora ili neuroblastoma. Ultrazvuk mokraćnog sustava kao dostupna i neinvazivna pretraga ima mjesto u obradi rane neonatalne žutice nepoznatog uzroka. Ultrazvučnim praćenjem regresije tvorbe može se izbjeći dodatna invazivna obrada i nepotrebna laparotomija.

Ključne riječi: Nadbubrežna žlijezda, bolesti; Krvarenje; Adrenalna insuficijencija; Žutica, neonatalna; Novorodenče 